\title{
Endangered Mammals in Peru
}

\author{
By Ian Grimwood
}

Major Ian Grimwood spent two years, 1965-67, in Peru, through the British Ministry of Overseas Development, as wildlife adviser to the Peruvian Government. His recommendation in his report for the establishment of the Manu National Park, a 4800-square-mile area of forest on the eastern slopes of the Andes, rich in wildlife, was accepted by the Peruvian Government in March 1968, as reported in ORYX May 1968, and the FPS allocated $£ 1000$ from the FPS/WWF Revolving Fund for this park. In an appendix to his main report Major Grimwood made a survey of the status of some Peruvian mammals, from which the following extracts concerning the more endangered ones are made. The chinchilla he considers to be undoubtedly extinct now in Peru.

TN PERU, the conservation of terrestrial mammals is the responsibility of the Servicio Forestal y de Caza (Forestry and Hunting), while marine mammals, including freshwater forms such as the two species of dolphins found in the Amazon tributaries, are in the care of the Servicio Pesqueria (Fisheries). In 1963, when the Servicio Forestal y de Caza came into being, there were no national parks or reserves to form sanctuaries for wild life and no regulations controlling hunting, other than a prohibition of the killing of vicuñas, fur seals and sealions, and a regulation prohibiting the killing of certain Amazon basin forms, including both species of peccary and brocket deer, during the period December 1st to March 31st, which was introduced to prevent the mass slaughter of animals that became isolated on islands of high ground during the annual floods, but proved to be virtually unenforceable. In May 1967 the Pampas Galeras National Reserve was created to form a sanctuary for vicuña*, and in March 1968 the 12,000-square-kilometre Manu National Park was set aside to preserve representative populations of the fauna and flora of the Amazon region in their natural state. The Servicio Forestal y de Caza is now selecting areas for the creation of national parks in the other two major divisions of the country, the coastal region and the Andes, and is considering a number of subsidiary reserves or sanctuaries to protect certain species which will not be represented in any of the three national parks. Regulations for the control of hunting in the rest of the country are also in preparation.

For the purposes of the report Peru is divided into the three major ecological divisions: the coastal, Andean and Amazon regions. The coastal region includes the coastal plain (mainly desert) and the western slopes of the Andes, rising to $3000-4000$ metres; the Andean the high mountains mainly above 3000 metres, and the Amazon the eastern slopes of the Andes.

*See ORYX, August 1966. 


\section{Primates - A Tale of Destruction}

In Peru primates are found only in the Amazon region, with the exception of the genera Alouatta and Cebus, both of which also occur to the west of the Andes. Besides being intensively hunted for food, by indigenous Indians and settlers alike, for the flesh of most species is highly esteemed, primates are subject to a form of exploitation not suffered by other animals, that is the capture and export of large numbers for medical research purposes and for the pet trade. Over 139,000 were exported alive between 1961 and 1965; 17,687 of them in 1961, 27,095 in 1962, 35,635 in 1963, 34,345 in 1964 and 24,384 in 1966. A breakdown of the 1964 total into genera is given below. The price shown against each genus is the price paid in soles for live specimens reaching Iquitos (1966 values: 75 soles $=£ 1$ ).

$\begin{array}{lrrlrr}\text { Genus } & \begin{array}{r}\text { Number } \\ \text { Exported }\end{array} & \begin{array}{r}\text { Local } \\ \text { Price }\end{array} & \text { Genus } & \begin{array}{r}\text { Number } \\ \text { Exported }\end{array} & \begin{array}{r}\text { Local } \\ \text { Price } \\ \text { Soles }\end{array} \\ \text { Aotus } & 356 & 100 & \text { Saimiri } & 27,353 & 80 \\ \text { Callicebus } & 54 & 150 & \text { Ateles } & 630 & 200 \\ \text { Cacajao } & 89 & 150 & \text { Lagothrix } & 2,081 & 300 \\ \text { Pithecia } & 81 & 100 & \text { Cebuella } & 972 & 100 \\ \text { Alouatta } & 3 & 50 & \text { Leontocebus } & 1,958 & 50 \\ \text { Cebus } & 2,574 & 200 & & & \end{array}$

Even in the most robust species, four or five individuals must die in the course of capture or during the long canoe journey to Iquitos, or while being held there, for every one that survives to be exported, and the low prices paid for Alouatta and Leontocebus reflect the high mortality of animals of those genera during even the few days that dealers have to hold them between weekly export flights.

It is difficult to assess the effect of this form of exploitation, but, even allowing for casualties, the number of individuals taken for export can be only a fraction of the number killed for food, in the case of most species. The combined effect of all forms of hunting, however, has been almost to eliminate all primates within a radius of many kilometres of settlements and the rivers which constitute the highways of the region. The radius of destruction is increasing yearly, with professional hunters and trappers pushing further into virgin country, and with the hunting of remote Indian tribes becoming commercialised as a result of the visits of skin and live-animal dealers. The survival of many species now seems to depend on how much of their natural territory will remain inaccessible to boats.

Control of the hunting of all primates is therefore necessary, as is control of the capture and export of live specimens. The latter measures should be framed to eliminate the cruelty from which captive animals now suffer, as well as to conserve the species in the wild.

The jaguar photograph is reproduced from South America, reviewed on page 433, by kind permission of the publishers. 


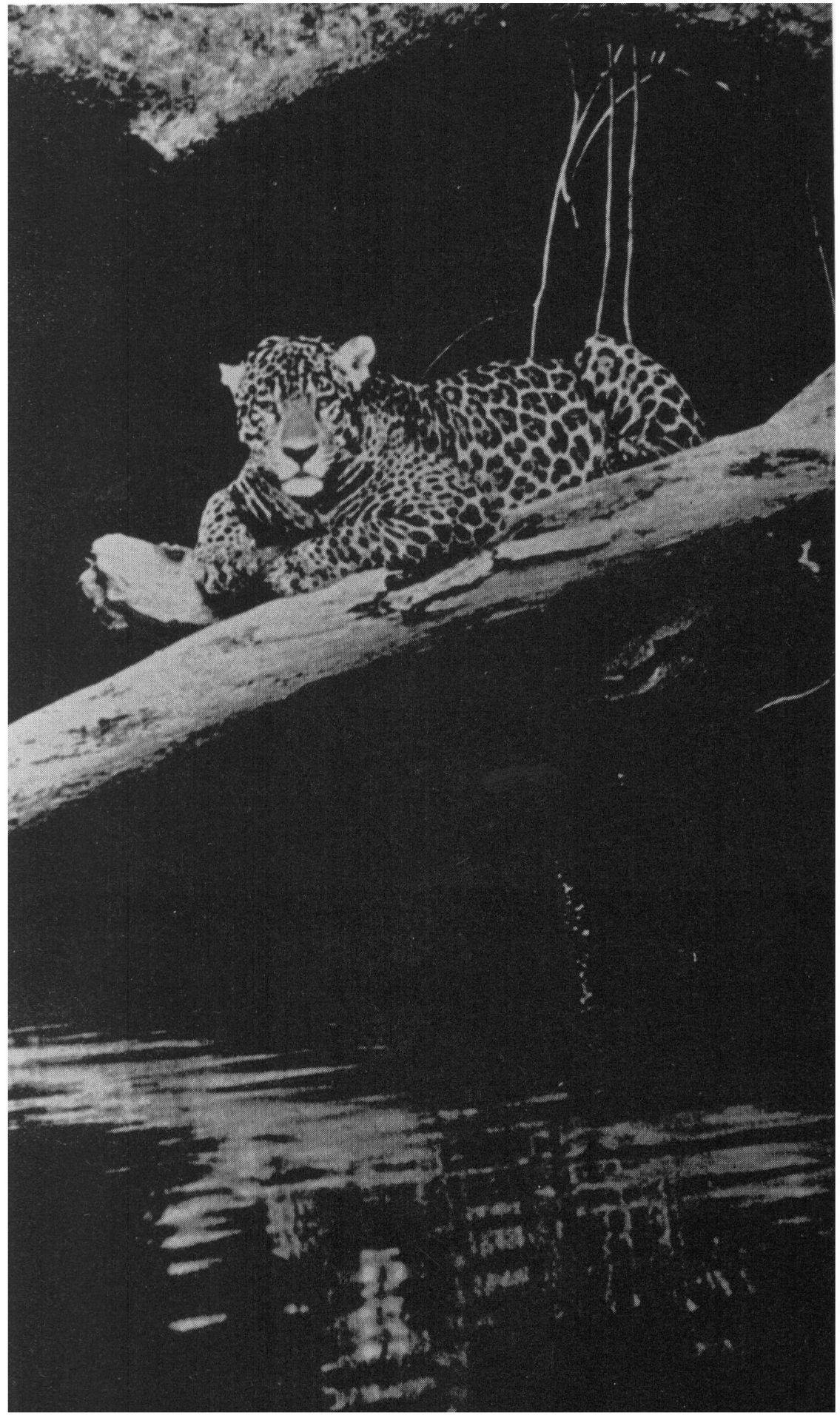




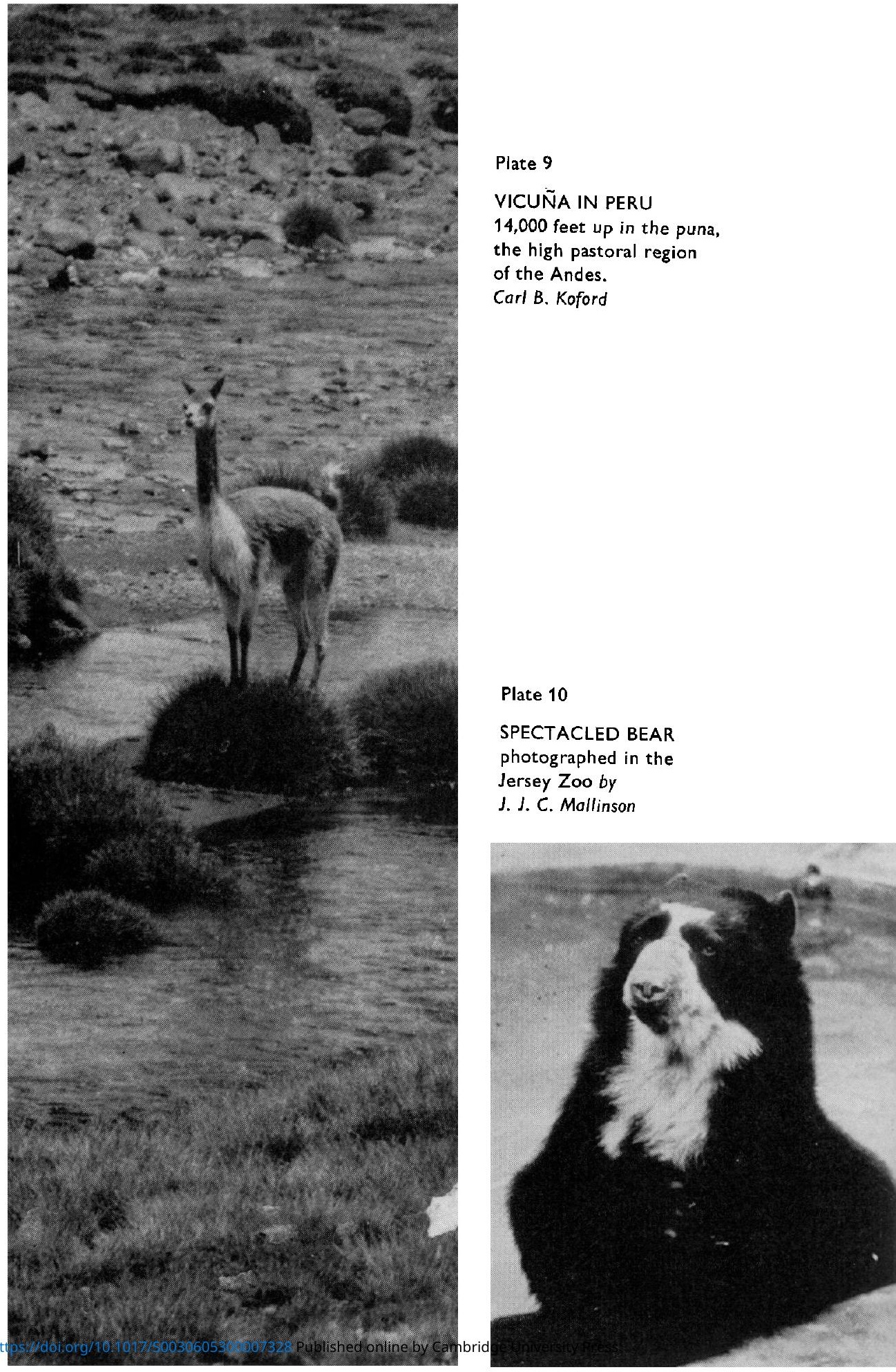




\section{Whales - Protection for Blue and Hump-back}

The sei whale Balaenoptera borealis, the fin whale $B$. physalus, the blue whale B. musculus, and the hump-back whale Megaptera novaeangliae, are all well known off the coast of Peru and in the past all but the first were intensively exploited by pelagic whalers of all nations. Whales of these species were not much hunted from shore-based stations in the early years following their establishment, because separate installations are necessary to keep their oil separate from that of sperm whales, to meet market requirements. A number were, however, killed in various attempts to popularise whale meat on local markets, which came to an end in 1956, by when altogether 101 fin whales, 37 blue whales and 37 hump-back whales had been taken. In 1964 the company operating at Paita, perhaps influenced by an increasing shortage of sperm whales, installed the necessary additional oil storage equipment and began to hunt those species again, killing 3 fin whales, 3 blue whales and 37 hump-back whales in that year. In 1965 the kill rose to $150 \mathrm{fin}, 80$ blue and 118 hump-back whales.

In 1966, however, the company declared its intention of killing no more blue or hump-back whales for a period of at least two years, in view of world-wide anxiety for the survival of these two species and the total protection accorded them in the South Pacific by member countries of the International Whaling Commission. Thanks to that generous gesture, and to the fact that no other whaling company is at present operating, blue whales and hump-back whales now enjoy de facto total protection in Peruvian waters. Regulations endorsing that are greatly to be desired.

As far as can be determined, no more than three or four sei whales have ever been killed by Peruvian shore-based whalers, possibly because they are not common, but more probably because sufficient numbers of the larger and more sought-after fin whale have always been available.

Giant anteater Myrmecophaga tridactyla: confined to the Amazon region, the species appears always to have been uncommon and has now disappeared from many areas where it was formerly known. If, as seems likely, it is confined to areas which do not flood, the spread of human settlement, which is subject to the same limitations, constitutes a serious threat to it. A number of live specimens are exported each year (e.g. 21 in 1964) and it is eaten in some areas. Control of hunting is necessary. It occurs in the Manu National Park. The collared anteater, the tamandus, found in the Amazon and the northern coastal regions, is commoner, but is killed in considerable numbers and control of hunting is desirable.

Pygmy or silky anteater Cyclopes didactylus: confined to the Amazon region and reported to be in the Manu park. Its small size, and arboreal and nocturnal habits, probably give it adequate protection in all but closely settled areas, but considerable numbers are taken for the live animal trade, most of which die before reaching the dealers in Pucallpa or Iquitos, or while awaiting export from those centres, through lack of care in accustoming them to an artificial diet. Many stuffed specimens are also sold as souvenirs. Control of hunting, or preferably the total protection of the species, is therefore necessary. 
Three-toed sloth Bradypus infuscatus (east of the Andes and on the coast): this sloth's dependence on Cecropia trees confines it largely to the river banks, where human settlement is also concentrated, and it is persecuted by man whenever encountered. Once detected it can neither defend itself nor escape. It is exported alive in some numbers (20 sloths of all species were exported in 1964) and many individuals must die for each one that survives capture. Large numbers of stuffed specimens are sold as souvenirs. Total protection of the species is advocated. It has been collected in the Manu National Park.

The status of the two-toed sloth Choloepus didactylus is similar and total protection is recommended.

Giant armadillo Priodontes giganteus (Amazon region including the Manu park): despite its wide distribution, this species is of solitary habits and appears always to have been uncommon. Its flesh is generally relished, and it has now disappeared from the vicinity of all settlement. Elsewhere it is subject to increasing hunting pressure. Total protection is therefore necessary.

The smaller armadillos Dasypus kappleri and Dasypus novemcinctus are highly prized as food wherever they occur and numbers have been greatly reduced in most areas of settlement. Control of hunting is therefore desirable.

Capybara Hydrochoerus hydrochaeris: confined to the low selva zone of the Amazon region, in which it has been recorded from the north to the south of the country. It is everywhere confined to the vicinity of rivers or lakes where there is aquatic vegetation or grassy stretches of bank, and is therefore absent from most of the smaller, tree-shaded rivers. It has suffered severely at the hands of man because it is restricted to the major rivers. Hunted both for food and for their hides by local residents and by bands of commercial hunters, capybaras have now disappeared from many waterways where they were formerly common, and elsewhere they have become almost entirely nocturnal in habit. Some idea of the numbers killed can be gained from the fact that in recent years Iquitos merchants have exported more than 10,000 of their skins annually, although the local price is no more than 20 soles each for them. The skins are valueless as furs and are used for making leather. A number of capybaras are exported alive, e.g. 59 in 1964. The species must be considered endangered throughout its range, and control of hunting is urgently required. Large and undisturbed populations of capybara exist in the Manu National Park, where they are still partly diurnal in habit.

Viscacha Lagidium peruanum (Chinchilla Family): typically animals of the puna and cordillera, usually between 3000 and 5000 metres, occurring in the Pampas Galeras vicuña reserve and the highest part of the Manu park. They are remarkably sparsely distributed throughout their range, ten or twenty kilometres often separating colonies in uniformly suitable country which provides all their requirements of food, water, and boulder piles in which to live. The reason for this is obscure. Viscachas are killed for food in many areas, but hunting alone does not seem to be responsible 
for their scarcity, since colonies survive quite close to human habitation in areas where they are most hunted. Unnaturally high populations of the Andean fox Dusicyon culpaeus, resulting from the introduction of domestic livestock, may be a major contributory cause, however. Whatever the reason for their relatively low numbers, present populations cannot withstand uncontrolled exploitation, and control of hunting is necessary.

Small-eared dog Atelocynus microtis (Amazon region, probably including the Manu park): must be regarded as everywhere rare. Not only is it insufficiently known to have a common (Spanish) name, but few hunters are even aware of its existence, or able to recognise a skin or a photograph of the animal. Total protection is therefore recommended.

Bush dog Speothus venaticus (eastern or north-eastern Peru): very rare and needing total protection.

Spectacled bear Tremarctos ornatus: in most parts of its range west of the Andes now exists only in small and widely-separated pockets few of which, because it is the most sought after of all trophies by sportsmen hunters, are likely to survive for much longer. Attempts have been made to preserve bears on some haciendas, but in most cases landowners are only too glad to see them destroyed because of their alleged cattle-killing proclivities. The status of the species is better to the east of the Andes, but even there bears have been exterminated, or almost exterminated, in all areas where they have come into contact with man. The species must therefore be regarded as rare and endangered throughout its range and strict control of hunting is necessary. The total Peruvian population is unlikely to be less than 800 or more than 2000 individuals. The upper part of the Manu National Park is well known for the number of bears it contains, and there are small numbers in the area of the proposed Cordillera Blanca National Park.

Kinkajou Potos flavus (Amazon region including the Manu): does not appear to be particularly rare, but is subject to increasing commercial exploitation. Exports of live animals run at more than 100 a year (143 in 1964) and large numbers of stuffed specimens are sold as tourist souvenirs. Kinkajou fur, too, has suddenly acquired some value, and 216 skins were exported in 1966. Should the demand for skins increase, the species could easily become endangered. Control of hunting is therefore necessary.

Coast otter Lutra felina: confined to rocky stretches of the south coast, and frequently killed because of its alleged damage to prawn stocks. Coast otters are also subject to much casual persecution by fishermen and by owners of firearms who find them convenient living targets. Whether as a result of human action or not, the species is now everywhere rare, and total protection is necessary. This otter has been recorded in all three areas under consideration for a coastal national park, but it is not known whether it is sufficiently local in habits to be contained in any one of them throughout the year. 
Amazon otter Lutra incarum (Amazon region including the Manu): its valuable pelt makes this otter one of the principal quarries of the professional fur and skin hunter, and in most waters within easy reach of settlement it has been exterminated. In 1966 the price paid for skins by dealers in Pucallpa and Iquitos was 450 soles ( $f 6$ ) each. Registered exports from Iquitos rose from 596 in 1946 to 11,349 in 1961 and 8,274 in 1966. It is improbable that any animal can sustain exploitation on that scale indefinitely. The fact that the annual take of skins shows no decline is not an indication that it is within the sustainable yield, but rather reflects the rapid expansion of settlement within the Amazon region, with more and more hunters taking part in a profitable business, and pushing further into virgin country each year to do their hunting. The true picture is almost certainly one of progressive extermination radiating from each centre of settlement, and such a process can only have one end. On the basis of 5 kilometres of river being required to sustain a pair of otters, the present off-take is the equivalent of eliminating the adult population from over 20,000 kilometres of waterways a year. Control of hunting, and particularly control of the trade in skins, which provides the incentive for hunting, is therefore urgently required.

Giant otter Pteronura brasiliensis: confined to the low selva zone of the Amazon region, it is principally found in the 'black water' regions of clear, but peat-stained lakes, lagoons and inter-connecting waterways that are found in the lower basins of the main Amazon tributaries. It has now disappeared from nearly all its former haunts and probably only small and isolated relict populations survive. The skin of the giant otter is only equalled in value by that of the jaguar, 1700 soles (£23) being paid for either by local dealers in 1966. In consequence, the animal has been so relentlessly hunted that it is undoubtedly approaching extinction. Total protection, and the prohibition of all trade in its skins, is therefore necessary. The totals of yearly exports of giant otter skins - 2107 in 1946 declining to 210 in 1966 - reflect the dwindling numbers, and show how its skins have nearly disappeared from the market despite the incentive of soaring prices and an ever-increasing number of hunters in the field. The species is well represented in the Manu National Park, and is probably present in very small numbers in the proposed Rio Samiria and Rio Pacaya Reserve.

Ocelot Felis pardalis: occurs in both the Amazon region, including the Manu, and the northern part of the coastal region, but is relentlessly hunted for its valuable pelt, for each of which 700 soles (£9) was paid by Iquitos and Pucallpa merchants in 1966. Dr Alfred Gardner informed me that during his three months' stay on the Rio Curanja no fewer than $\mathbf{4 0}$ to $\mathbf{5 0}$ of those animals were trapped by the inhabitants of a single Indian village and that traders visited the area buying skins each month. Over 138,000 ocelot skins have been exported from Iquitos during the last 20 years, the annual figures rising from 1816 in 1964 to 14,894 in 1966. The ocelot is undoubtedly one of the most successful forms of mammalian life in the Amazon region and is often more plentiful than the availability of 
prey species would appear to make possible, but it is impossible for the species to withstand such a drain on its population indefinitely. It has not been entirely eradicated from all areas of settlement, but, as in the case of Lutra incarum, the high off-take can only have been maintained by the decimation of the population in new areas every year. Control of hunting, and particularly of the trade in skins is therefore necessary.

Puma Felis concolor: occurs in all three regions of Peru, and shows a remarkable ability to adapt itself to habitats as different as the arid rocky western slopes of the Andes, the bleak and freezing regions of the puna and cordilleras, and the tropical forests of the low selva. It is everywhere notorious as a stock killer, but it is difficult to hunt and tenacious of existence. Although numbers are usually small, it has not been eradicated from any part of its range. Its skin has no commercial value. Despite its apparently satisfactory status, control of hunting is desirable.

Jaguar Panthera onca: occurs throughout the low selva of the Amazon region including the Manu, up to about 1000 metres. Long persecuted for its valuable skin, for which local merchants were paying 1700 soles (£23) each in 1966, it has disappeared from the neighbourhood of all settlement and is now rare in many parts of its former range. Altogether 12,704 jaguar skins were exported from Iquitos in the 20 years prior to 1966, annual totals rising from 353 in 1964 to 1113 in 1965 and 891 in 1966. Little is known of the population dynamics of this species, but it seems most unlikely that that rate of off-take can be sustained. Control of hunting and the trade in skins, is therefore necessary.

South American sealion Otaria flavescens: formerly very numerous, but reduced to near vanishing point by indiscriminate hunting in the early decades of this century. Dr Alvaro A. Piazza cites an example of a single dealer being able to buy 36,650 skins of this species and of the fur seal Arctocephalus australis on a short stretch of coast in a period of four months in 1941-42. In 1959 hunting was prohibited and since then the species has slowly recovered, until in 1966 the Servicio Pesqueria estimated the Peruvian population to be about 20,000 . The sealion formerly bred in a variety of sites, including open beaches, but it is now confined to a number of precipitous rocky islands and headlands where rough seas cause so many casualties amongst young animals that its rate of recovery has probably been slowed. A considerable number of sealions are still killed illegally, mainly by small-boat fishermen, who suffer some damage to their nets. Hunting should not be resumed until the population has further recovered, when these animals can be exploited on a sustained-yield basis.

Southern fur seal Arctocephalus australis (southern part of the coast): never as plentiful as the sealion, because it was more heavily hunted for its much more valuable pelt, it came even nearer to being exterminated. It, too, has been protected since 1959 and the Servicio Pesqueria's estimate of the total Peruvian population in 1966 was $4000-5000$. The only breeding site known to be used during the 1965 and 1966 seasons was that at the 
foot of the cliffs of the Paracas peninsula, where approximately 2000 animals were counted on several occasions. This species is in greater need of further protection before hunting is resumed than is Otaria flavescens.

Manatee Trichechus inunguis: confined to the sytem of 'blackwater' lakes, lagoons and waterways associated with the lower reaches of the main tributaries of the Amazon. Ruthless hunting for its meat has brought it nearer extinction than perhaps any other mammal of the Amazon region. It is now so rare that only by the prohibition of all hunting can the species be saved. An example of the way that manatees have been persecuted in the past is the two traders encountered by an officer of the Servicio Forestal in 1958, who were bringing back 10,000 kilos of dried meat from an expedition to the Rio Putamayo, which represents 220 average-sized adult animals.

South American tapir Tapirus terrestris (Amazon region including the Manu park): is everywhere hunted for its meat, although that is not greatly esteemed; it has managed to survive in fair numbers in most parts of its range, partly perhaps because its hide has no commercial value, and partly because it is able to utilise low land remote from man and is not forced to concentrate on river banks and other high ground during the flood season. Control of hunting is, however, desirable.

Mountain or woolly tapir $T$. pinchaque (only in the north): the mountain tapir does not appear to be much persecuted by hunters, but the species is said to be intolerant of disturbance and to be disappearing from areas where it was formerly common. It is rare throughout the remainder of its range in Ecuador and Colombia and is included in the IUCN List of Endangered Species. The Peruvian population cannot number more than one or two hundred individuals. Total protection and the creation of some form of sanctuary is therefore recommended.

Collared peccary Tayassu tajacu (Amazon and northern part of the coastal region): an important source of food for almost all residents of the Amazon region, and also intensively hunted for its hide by commercial hunters (whose wasteful methods often entail throwing away the meat), despite the fact that each hide is worth no more than $25-30$ soles $(7 s-8 s)$. Over two million hides of this species were exported from Iquitos during the period 1946-66, 690,000 of them in the last five years, which, if they represent but 60 per cent of all animals killed, is the equivalent of an annual off-take of one peccary for each 1.6 square kilometres $(0.64$ square mile) of the whole Amazon region. The number of hides exported rose from 70,876 in 1964 to 181,209 in 1966. Although the species is still quite common in most parts of its range, it is difficult to believe that it can withstand a drain of that nature indefinitely. Control of hunting, and of the trade in skins, is therefore necessary if this valuable species is to be conserved.

White-lipped peccary $T$. albirostris (Amazon region including the Manu): less numerous than T. tajacu, although it occurs in larger bands, which often 
number up to 100 individuals, compared with 10 to 20 in the case of the latter. It is also more nomadic. It is subject to the same hunting pressures, despite its hide being of even less value and fetching no more than 8-10 soles $(2 s-2 s 6 d)$ each. Over 848,000 hides were exported between 1946 and 1966, and the average off-take for the last five years was the equivalent of one animal per $4 \cdot 5$ square kilometres ( 1.8 square miles) of the whole Amazon region, on the same basis of calculation as was used in the case of $T$. tajacu. Control of hunting, and of the trade in skins, is necessary.

Vicuña Vicugna vicugna: confined to the puna country of the Andean region south of $9^{\circ} 30^{\prime} \mathrm{S}$. The prohibition of the killing of this species, and of the export of its wool, which has been in force for many years, has proved ineffectual and the vicuña now faces extinction throughout most of its range. The incentive for illegal hunting is the value of its wool, of which an adult animal will produce one third to half a pound, worth up to US $\$ 25$ per pound. Much of the killing is done by commercial poachers from the cities, equipped with motor vehicles and precision weapons, but many young animals are picked up by herdsmen, whose dogs also exact a toll. Most of the wool is said to be smuggled into Bolivia, where it can be legally sold, or to be exported hidden in bales of alpaca or sheep's wool*. The decline in the status of the vicuña is so serious that concerted action to stop dealings in its wool in all South American countries, and banning imports into manufacturing countries, appears necessary to save the species from extinction.

Through the generosity of the Comunidad de Lucanas, who own the land, 6500 hectares of the Pampas Galeras have been set aside as the Pampas Galeras National Reserve, for vicuñas. The reserve usually holds from 400 to 600 animals, and the guards stationed there afford protection to as many more in neighbouring areas. The Government is also negotiating the purchase of Hacienda Cala Cala with a view to separating the hybrid from the pure-bred stock of vicuñas there and establishing a second reserve.

Guanaco Lama guanicoe: found in the Andean and coastal regions of the southern half of the country at elevations of from sea level up to 4000 metres, guanacos were formerly plentiful in many parts of the coastal region, mainly on the upper slopes of the mountains, where sparse grazing is obtainable at all times of the year, and appearing also on the lomas of the coastal plain during the period of winter flush. The one remaining big population of this species exists at the northern end of its range in the Andean region, where they have been protected by the owner of a hacien$\mathrm{da}$, who estimates that by 1965 he had approximately 1000 animals on his land, despite regular culling for labour rations. In that year, however, they were reduced by disease, and only 400 to 500 are believed to remain.

The guanaco is now a very rare animal, in imminent danger of extinction in the few areas where it still exists. Numerically it is in an even worse plight than the vicuña, and it seems improbable that the total Peruvian population can exceed 5000 . Its decline can be attributed solely to hunting, 
and total protection is therefore necessary. It is not represented in any existing or projected national park or reserve, and a special guanaco sanctuary is therefore desirable.

White-tailed deer Odocoileus virginianus (widespread): remorselessly hunted wherever it occurs, males and females being killed indiscriminately and hunting continued through all seasons of the year. As a result, this deer has become a shy and almost entirely nocturnal animal, nowhere common except on the few haciendas on which it is preserved. Nevertheless, it shows remarkable tenacity as a species and has been entirely eradicated only from surprisingly few parts of its range. Control of hunting is necessary.

Red brocket deer Mazama americana: still fairly abundant in many parts of its range, which includes the Manu, the red brocket deer has disappeared from the vicinity of almost all settlement. It is subject to intensive commercial hunting for its hide, as well as for food, and is particularly vulnerable during the flood season, when the populations of large areas may be concentrated on small islands of dry ground. Control of hunting, and of the trade in skins, is therefore necessary.

The average price paid for hides when delivered to merchants in Iquitos or Pucallpa is no more than 21 soles ( $5 s 6 d$ ) each. Nevertheless, 35,000 to 40,000 are now exported annually.

Brown brocket deer $M$. gouazoubira: numerically everywhere less common than $M$. americana, and subject to the same hunting pressures, although its flesh is less esteemed and there are prejudices about eating it in a few areas. The very much smaller number that is killed is therefore probably a true reflection of its relative scarcity. Control of hunting, and of the trade in skins, is necessary. It is found in several parts of the Manu park.

Dwarf brocket deer $M$. chunyi (found only in two departments, Cuzco and Puno in the south-east) destruction of habitat appears to present a greater threat to this species, in the areas in which I know it, than does hunting, as firearms are few, no form of trap or snare is used, and only a few animals are caught by hand or killed by dogs. Land clearing for agricultural purposes, however, is beginning to make serious inroads into the deer's somewhat restricted habitat, particularly in valleys to the west of the main watershed. Control of hunting is necessary.

Pudu Pudu mephistopheles: it is improbable that this species will survive for much longer in the isolated forest patches in which it occurs in the upper Huallaga basin, where it is relentlessly hunted with dogs and guns. It has, however, outlasted the white-tailed deer in many of them, because it does not break cover as does that species, but circles amongst the dense thickets and cliffs, where it is said to be as nimble on rock as a klipspringer. Destruction of habitat for settlement is also a serious threat. Control of hunting is, however, necessary. Because the pudu does not occur in any 
existing or projected national park or reserve, the creation of a special sanctuary, for which the high ground above the San Ramon gorge is suggested, is therefore desirable

Guemal Hippocamelus antisensis (Andean region above 4300 metres): although this deer is widespread, its total population is small. Its specialised habitat means that it lives in isolated communities and runs the risks inherent in such a situation. Hunting has eliminated it from almost all the lower parts of its former range and it is much persecuted wherever it still exists. Guemals are reported to be rather foolish animals and to be easily slaughtered once the leader of a group has been killed. The species shows none of the tenacity of Odocoileus virginianus and appears to be in delicate balance everywhere. Control of hunting is very necessary. The highest ridge of what is now the Manu National Park was formerly a wellknown haunt of this species and small numbers are thought still to exist there.

\section{The Spectacled Bear}

TTHE spectacled bear, the only bear in South America, is listed in the IUCN Red Book as an endangered species on the strength of the recommendation of the Seattle Conference on National Parks in 1962 that it was threatened with extinction. However, Dr Albert W. Erickson, of Minnesota, who has made a survey for the World Wildlife Fund of this bear's status in the five Latin American countries in which it occurs Venezuela, Colombia, Ecuador, Peru and Bolivia - thinks it "highly improbable that the spectacled bear is in any immediate danger of extinction', though he adds that early consideration should be given to taking steps to preserve the species. In a brief report in the WWF report for 196567, The Ark Under Way, he writes: 'In Venezuela, the northern limits of the species' range, the spectacled bear is now, and probably always has been, quite rare. This judgement is based on the fact that there are very few records of the spectacled bear from Venezuela and only one person was contacted who had even so much as observed signs of the bear on a single occasion.

'In Colombia, the spectacled bear is still to be found in portions of the west, east and central Andes mountains, although best evidence suggests that its distribution and presumed abundance in each of these ranges is markedly reduced from former times.

'The apparent status of the spectacled bear in Ecuador appears very good with near pristine populations remaining throughout the country, although agricultural activities have encroached on the bear's range along the entire valley separating the east and west ranges. However, inasmuch as the spectacled bear is infrequently found anywhere below 2000 feet, it appears unlikely that such encroachment has appreciably affected bear numbers in Ecuador.

'In Peru, as in Colombia, major reductions in the distribution of the spectacled bear are apparent. Nevertheless, the species is still found along 